\title{
Ketidaktepatan Kode Diagnosis Kasus Neoplasma Menggunakan ICD-10 Di RSUP H.Adam Malik Medan Tahun 2019
}

\author{
Johanna Christy ${ }^{1}$, Evi Efriamta Siagian² \\ ${ }^{1,2}$ Program Studi D-4 Manajemen Informasi Kesehatan, Universitas Imelda Medan
}

\begin{tabular}{l}
\hline Article Info \\
\hline Article history: \\
Received Jan 01, 2021 \\
Revised Feb 16, 2021 \\
Accepted Feb 19, 2021 \\
\hline
\end{tabular}

Keywords:

Accuracy

Diagnosis

Neoplasm

Encoding

\begin{abstract}
ABSTRAK
Information for patients in hospitals will not be complete and useful if it has not been processed, so coding is necessary. One of the factors that caused the inaccuracy in coding was that the coding officer was difficult to read the writing besides that the coding officer had not fully implemented the rules and regulations for giving the diagnosis code based on ICD-10. This study aims to determine the accuracy of the diagnosis code in cases of neoplasm using ICD10 in RSUP H.Adam Malik in 2019. This research is a qualitative research with a descriptive approach, the number of samples used was 93 documents of inpatient medical records for neoplasm cases and 4 PMIK respondents. The accuracy of the morphological code for the diagnosis of neoplasm was $88(95 \%)$ the code was exactly 6 characters, $0(0 \%)$ the code was exactly 5 characters, $0(0 \%)$ the code was exactly 4 characters, $3(3 \%)$ the code was not correct at all and 2 $(2 \%)$ is not coded. The accuracy of the topographic code is $79(85 \%)$ the code is exactly 4 characters, $8(9 \%)$ the code is exactly 3 characters, $4(4 \%)$ the code is exactly 2 characters, $0(0 \%)$ the code is exactly 1 character, $0(0 \%)$ code is not correct at all and code $0(0 \%)$ is not working. The factor that caused the inaccuracy in coding was that it was difficult for coding officers to read the doctor's writings, so the authors suggested that the coding of the diagnosis should still follow the rules and regulations in ICD-10.
\end{abstract}

This is an open access article under the CC BY-SAlicense.
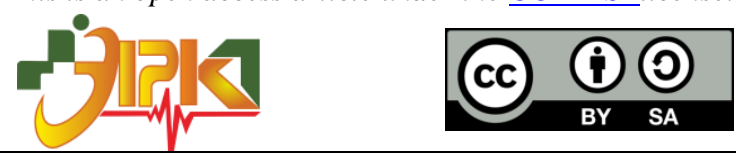

\section{Corresponding Author:}

Johanna Christy,

Program Studi D-4 Manajemen Informasi Kesehatan,

Universitas Imelda Medan,

Jl. Bilal No. 52 Kelurahan Pulo Brayan Darat I Kecamatan Medan Timur, Medan - Sumatera Utara.

Email: Johanna.hasibuan@yahoo.co.id

\section{PENDAHULUAN}

Koding merupakan salah satu kegiatan pengolahan data rekam medis untuk memberikan kode dengan huruf atau mengklasifikasikan penyakit dengan pengelompokan penyakit yang sejenis kedalam satu grup nomor kode penyakit.Agar dapat menentukan kode dengan etnis dan tepat, koder profesional harus memiliki pemahaman yang jernih tentang sumber terpercaya untuk kaidah koding yang digunakan (Yunita, 2016).

Tata cara penetapan kode ditentukan oleh perangkat koding yang di gunakan di Indonesia, khususnya untuk kepentingan reimbursment menggunakan ICD-10 versi th. 
2010 untuk kode diagnosis penyakit sedangkan untuk koding prosedur medis menggunakan ICD-9-CM versi th 2010 (Permenkes No 76 tahun 2016).

ICD-10 (International Statistical Classification of Diseases and Related Health Problem) merupakan acuan dalam melakukan proses coding dengan berbagai penyakit yang terbagi dalam 22 bab. Dimana salah satu bab dalam ICD-10 membahas penyakit tentang neoplasma. Neoplasma merupakan penyakit pertumbuhan sel yaitu yang terdiri dari sel-sel baru yang mempunyai bentuk, sifat dan kinetika yang berbeda dari sel normal asalnya. Dalam penanganan kasus ini dibutuhkan tindakan dan runtutan pengobatan yang kompleks sehingga diperlukan kode penyakit yang yang lebih spesifik sehingga dapat menggambarkan kondisi penyakit secara lebih detail/lengkap (Dewa Gede, 2012). Ada tiga aspek yang harus dipertimbangkan ketika menentukan kode neoplasma yaitu lokasi tumor menujukkan dimana lokasi tumor berada, sifat tumor (menggambarkan struktur dan jenis selaput jaringan dibawah mikroskop), perilaku (ganas, jinak dan insitu) pada ICD-10 terklasifikasi pada bab II kode C00-D48 (WHO, 2010).

Berdasarkan penelitian yang dilakukan oleh (Irma Yunita, 2016) dengan judul "Ketepatan Kode Diagnosis Pada Kasus Neoplasma Di Rumah Sakit Panti Wilasa Citarum Tahun 2015 menyatakan bahwa Ketepatan kode morfologi pada diagnosis neoplasma diperoleh hasil $10 \%$ kode tepat 6 karakter, $0 \%$ kode tepat 5 karakter, $0 \%$ kode tepat 4 karakter, $0 \%$ kode tepat 3 karakter, $0 \%$ kode tepat 2 karakter, $0 \%$ kode tepat 1 karakter dan $100 \%$ tidak dikode. Ketepatan kode topografi diperoleh hasil 72,59\% kode tepat 4 karakter, $27,41 \%$ kode tepat 3 karakter, $0 \%$ kode tepat 2 karakter, $0 \%$ kode tepat 1 karakter, $0 \%$ kode tidak tepat sama sekali. Tata cara pengodean neoplasma di RS Panti Wilasa Citarum belum sesuai dengan kaidah ICD-10 dengan persentase ketepatan kode Topografi 72,59\% dan kode Morfologi 0\%.

RSUP H.Adam Malik ini beralamat di Jalan Bunga Lau No. 17. Medan, terletak dikelurahan Kemenangan, kecamatan Medan Tuntungan. Letak RSUP H.Adam Malik ini berada di daerah pedalaman yaitu berjarak kira-kira $1 \mathrm{Km}$ dari jalan Djamin Ginting atau jalan umum yang merupakan jalan raya menuju ke arah Berastagi.

Berdasarkan hasil studi pendahuluan di RSUP H.Adam Malik, cek dokumen yang dijadikan sampel yaitu sebanyak 5 dokumen, yang dilakukan pada tanggal 16 Maret 2020, di RSUP H. Adam Malik Medan masih ditemukan penulisan kode diagnosis neoplasma yang belum tepat. Dalam pemberian kode diagnosis neoplasma petugas coding masih ada belum mencantumkan kode morfologi yang yang menunjukkan keganasan dari neoplasma tersebut. Ketidaktepatan kode diagnosis juga masih ditemukan karena petugas coding belum menerapkan sepenuhnya aturan dan ketentukan pemberian kode diagnosis berdasarkan ICD-10.

Selain itu, berdasarkan hasil wawancara dengan salah satu petugas coding di RSUP H.Adam Malik Medan menjelaskan untuk evaluasi ketepatan hasil kode diagnosis khususnya neoplasma pada tahun 2019 belum pernah dilakukan evaluasi. Penyakit neoplasma juga termasuk kedalam 10 besar penyakit yang harus dikode secara tepat dan akurat oleh petugas koding. Apabila kode diagnosis masih ada tidak tepat/tidak sesuai dengan ICD-10 maka akan berpengaruh bagi rumah sakit dan dapat menimbulkan turunnya mutu pelayanan di rumah sakit serta dapat mempengaruhi data dalam pembuatan laporan internal maupun eksternal rumah sakit.

\section{METODE PENELITIAN}

Penelitian ini merupakan penelitian kualitatif dengan pendekatan deskriptif. Penelitian ini dilakukan pada bulan Juni-Juli 2020. Adapun variabel-variabel yang diamati oleh peneliti adalah tata cara pengodean diagnosis neoplasma, ketepatan kode diagnosis 
neoplasma, faktor yang mempengaruhi ketidaktepatan kode diagnosis neoplasma dan hasil ketepatan kode diagnosis neoplasma

Keseluruhan objek yang diteliti yaitu dokumen rekam medis pasien rawat inap dengan penyakit neoplasma. Populasi pada penelitian ini adalah berkas rekam medis rawat inap pada formulir ringkasan riwayat masuk dan keluar (RM 1) dan resume keluar bulan Januari-Maret tahun 2019 dengan jumlah populasi sebanyak 1325 dokumen rekam medis. Sampel yang diambil adalah sebanyak 93 dokumen rekam medis dengan metode penelitian sampel yaitu metode acak atau Systematic Random Sampling.

\section{HASIL DAN PEMBAHASAN}

\subsection{Hasil}

\section{Tata Cara Pengodean Diagnosis Neoplasma di Rumah Sakit H. Adam Malik Medan}

Dari hasil penelitian yang dilakukan di Rumah Sakit H. Adam Malik Medan, untuk pengodean dibagi menjadi 3 yaitu coding rawat jalan, coding rawat inap, dan coding INA CBG's. Coding rawat jalan dikerjakan oleh tiga orang petugas. Coding rawat inap dikerjakan oleh dua orang petugas yang mana juga merangkap sebagai petugas pelaporan. Sedangkan bagian untuk pengodean INA CBG's dikerjakan oleh dua orang petugas. Pengodean di Rumah Sakit H. Adam Malik Medan dilakukan secara komputerisasi.

Diagnosis utama neoplasma di Rumah Sakit H.Adam Malik Medan ditulis pada formulir ringkasan riwayat masuk dan keluar (RM 1) pada resume keluar. Dimana dalam melakukan kodefikasi diagnosis neoplasma ada beberapa hal yang harus perhatikan yaitu topografi dan morfologi. ICD-O merupakan klasifikasi penyakit dengan sistem pengkodean untuk topografi dan morfologi. Kode topografi menggunakan untuk hampir semua neoplasma, kategori-kategori 3- dan 4- karakter yantg digunakan pada ICD-10 memberikan kespesifikan yang lebih besar mengenai penyakit neoplasma tidak-ganas dibandingkan dengan ICD-10.

Kode morfologi memiliki 5 digit, empat pertama mengindentifikasikan jenis jaringan dan digit kelima menunjukkan sifat neoplasma tersebut (ganas, insitu, jinak dll). Kode morfologi juga didapatkan dari ICD-10 volume 1 dan ditambahkan pada entry yang sesuai pada volime 3. Jadi, Diagnosis penyakit neoplasma ini didapatkan dari penyakit utama yang diderita oleh pasien. Selain dari pada penyakit utama yang diderita oleh pasien, juga berdasarkan pada kondisi klinis dan ditunjang dengan hasil pemeriksaan penunjang berupa pemeriksaan patologi anatomi (PA). Kemudian diagnosis penyakit utama neoplasma di coding menggunakan ICD-10 dan hasil kodenya ditulis pada dokumen rekam medis di formulir ringkasan riwayat masuk dan keluar (RM 1) yang dilaksanakan oleh petugas coding. Peneliti melakukan observasi pada proses pengodean diagnosis yang dilakukan oleh petugas coding. Hasil observasi proses pengodean diagnosis di Rumah Sakit H.Adam Malik Medan dapat dilihat pada tabel berikut:

Tabel 1. Check List Observasi Pengodean Diagnosis

\begin{tabular}{llll}
\hline No & \multicolumn{1}{c}{ Aspek yang diamati } & Ya & Tidak \\
\hline 1. & $\begin{array}{l}\text { Petugas coding membuka formulir ringkasan masuk dan keluar } \\
\text { pada dokumen rekam medis. }\end{array}$ & $\sqrt{ }$ & \\
\hline 2. & $\begin{array}{l}\text { Petugas coding membaca diagnosis yang yang telah dituliskan } \\
\text { dokter }\end{array}$ & $\sqrt{ }$ \\
\hline 3. & $\begin{array}{l}\text { Petugas coding melihat hasil dari pemeriksaan penunjang (bagi } \\
\text { yang sudah ada hasilnya) }\end{array}$ & $\sqrt{ }$ \\
\hline 4. & Petugas coding mencari leadterm/kata kunci terlebih dahulu & $\sqrt{ }$ \\
\hline $\begin{array}{l}\text { Petugas coding terlebih dahulu menentukan pilihan kode istilah } \\
\text { diagnosis sesuai dignosis yang tertera pada lembar ringkasan } \\
\text { masuk dan keluar pada ICD-10 Volume 3 dengan }\end{array}$ & \\
\hline
\end{tabular}


memperhatikan semua perintah, keterangan, includes, excludes, use additional code dan lain-lain yang menyertainya.

6. Petugas coding mencocokkan hasil kode diagnosis yang ada di ICD-10 Volume 3 dengan yang ada di ICD-10 Volume 1

7. Menuliskan hasil kode diagnosis di lembar ringkasan masuk

7. dan keluar pada dokumen rekam medis.

Pengodean diagnosis neoplasma oleh petugas coding di Rumah Sakit H.Adam Malik Medan tidak menggunakan ICD-10 Volume 1 dan 2 untuk mengkode penyakitnya. Hal ini didapatkan dari hasil observasi dan pertanyaan-pertanyaan yang diberikan kepada petugas koding. Dimana petugas membuka lembar catatan keperawatan dan apabila tidak terbaca maka petugas langsung menanyakan kepada dokter yang bersangkutan, kemudian setelah itu membuka hasil pemeriksaan PA (Patologi Anatomi). Berikut ini merupakan Tabel hasil observasi oleh peneliti mengenai tata cara pengodean yang dilakukan oleh petugas coding jika diagnosis susah dibaca.

Tabel 2. Check List Observasi Tata Cara Pembacaan Diagnosis

\begin{tabular}{cllll}
\hline No & \multicolumn{1}{c}{ Aspek yang diamati } & Ya & Tidak \\
\hline 1. & Petugas membuka lembar catatan keperawatan & $\sqrt{ }$ & \\
\hline 2. & $\begin{array}{l}\text { Apabila belum terbaca, petugas menanyakan langsung } \\
\text { kepada dokter yang bersangkutan }\end{array}$ & $\sqrt{ }$ \\
\hline 3. & $\begin{array}{l}\text { Membuka hasil pemeriksaan laboraturium PA (Patologi } \\
\text { Anatomi) }\end{array}$ & $\sqrt{ }$ \\
\hline
\end{tabular}

Berdasarkan hasil penelitian mengenai tata cara kodefikasi diagnosis neoplasma di Rumah Sakit H. Adam Malik Medan tidak menggunakan ICD-10 Volume 1 dan ICD-10 volume 2. Pengodean diagnosis berdasarkan pada ICD-10 Volume 3. Setelah mendapatkan leadterm kata kunci petugas langsung mencari kode diagnosis pada ICD-10 Volume 3. Setelah kode diagnosis ditemukan, petugas langsung memasukkan kode tersebut ke dalam aplikasi pengodean dan menuliskan kode diagnosis pada lembar ringkasan masuk dan keluar. Berdasarkan hasil wawancara dengan petugas coding di Rumah Sakit H.Adam Malik Medan, dalam pengodean diagnosis tidak memerlukan ICD-10 Volume 1 maupun ICD-10 Volume 2. Kode dignosis yang ditemukan pada ICD-10 Volume 3 langsung diinputkan ke dalam aplikasi pengodean. ICD-10 Volume 1 dan ICD-10 Volume 2 digunakan apabila terdapat kasus baru.

Hal ini tidak sesuai dengan SOP Rumah Sakit H. Adam Malik Medan dan bertentangan dengan aturan dan tata cara pengodean diagnosis yang terdapat pada ICD-10 Volume 2. Di dalam ICD-10 Volume 2 (2010), dijelaskan untuk mendapatkan hasil kode diagnosis yang akurat setelah menemukan kode diagnosis pada ICD-10 Volume 3 kemudian dicocokkan dengan hasil kode yang terdapat pada ICD-10 Volume 1. Hal tersebut dilakukan guna mengurangi kesalahan dan ketidaktepatan dalam menentukan kode diagnosis.

\section{Ketepatan Kode Diagnosis Neoplasma di Rumah Sakit H.Adam Malik Medan}

Pada penelitian ini, peneliti mengambil sampel sebanyak 93 dokumen rekam medis rawat inap sesudah dilakukan analisis kelengkapan dengan diagnosis utama neoplasma bulan Januari sampai dengan bulan Maret 2019. Studi dokumentasi yang dilakukan peneliti adalah dengan mencatat nomor rekam medis, diagnosis penyakit pada dokumen rekam medis rawat inap dan mencatat kode diagnosis pada dokumen rekam medis. Kemudian peneliti mengambil data dari dokumen rekam medis rawat inap berupa diagnosis utama dan kode diagnosis pada lembar ringkasan masuk dan keluar (RM 1). 
Untuk mengetahui tingkat ketepatan kode diagnosis neoplasma dengan ICD-10 di Rumah Sakit H. Adam Malik Medan, peneliti membandingkan hasil kode yang ada pada lembar ringkasan masuk dan keluar (RM 1) dengan menggunakan ICD-10 volume 1 dan dengan kode koreksi yang berasal dari pakar coding. Di dalam dokumen rekam medis ringkasan masuk dan keluar (RM 1) ada sebagian dari dokumen rekam medis tersebut tidak terdapat kode morfologi. Untuk hasil analisis ketepatan kode diagnosis ditunjukkan pada tabel berikut:

Tabel 3. Analisis Ketepatan Kode Morfologi Diagnosis Neoplasma

\begin{tabular}{clcc}
\hline No & Aspek Ketepatan Kode & Jumlah & Presentase \\
\hline 1. & Tepat 6 karakter & 88 & $95 \%$ \\
\hline 2. & Tepat 5 karakter & 0 & 0 \\
\hline 3. & Tepat 4 karakter & 0 & 0 \\
\hline 4. & Tepat 3 karakter & 0 & 0 \\
\hline 5. & Tepat 2 karakter & 0 & 0 \\
\hline 6. & Tepat 1 karakter & 0 & 0 \\
\hline 7. & Tidak tepat sama sekali & 3 & $3 \%$ \\
\hline 8. & Tidak dikode & 2 & $2 \%$ \\
\hline & Total & $\mathbf{9 3}$ & $\mathbf{1 0 0 \%}$ \\
\hline
\end{tabular}

Sumber: Data Sekunder Rekam Medis Tahun 2019

Pada tabel diatas dapat dilihat ketepatan kode morfologi diagnosis neoplasma tahun 2019 pada dokumen rekam medis rawatinap yang dilakukan di Rumah Sakit H.Adam Malik Medan setelah diteliti berdasarkan ketepatan tiap-tiap karakternya didapatkan hasil $88(95 \%)$ kode tepat 6 karakter, $0(0 \%)$ kode tepat 5 karakter, $0(0 \%)$ kode tepat 4 karakter, $0(0 \%)$ kode tepat 3 karakter, $0(0 \%)$ kode tepat 2 karakter, $0(0 \%)$ kode tepat 1 karakter, 3 (3\%) kode tidak tepatsama sekali,dan 2 (2\%) tidak dikode. Petugas coding di Rumah Sakit H.Adam Malik Medan masih ada yang tidak mencantumkan kode morfologi.

Berdasarkan hasil analisis terhadap ketepatan kode diagnosis morfologi pada kasus neoplasma di Rumah Sakit H.Adam Malik Medan Januari sampai dengan Maret 2019 (lihat tabel 3), dapat dilihat bahwa presentase ketepatan kode diagnosis morfologi masih ada yang kurang tepat. Presentase pada hasil analisis ketepatan kode diagnosis dengan kategori enam karakter menunjukkan masih ada yang tidak tepat sama sekali dengan jumlah persentase $3 \%$. Sedangkan presentase untuk kode diagnosis morfologi yang tidak dikode menunjukkan angka $2 \%$ dari 93 dokumen rekam medis.

Pencantuman kode morfologi untuk pengodean kasus neoplasma sangat penting. Di dalam ICD-10 Volume 2 (2010), dijelaskan kode morfologi terdiri dari 6 digit yaitu M8000/0 sampai dengan M9989/3 yang berguna untuk menentukan tipe dari neoplasma atau menunjukkan tingkat keganasan dari neoplasma tersebut. Digit terakhir, menentukan sifat dari neoplasma. Sebagai contoh kode C53.9. Kode C53.9 jika ditulis dengan kode morfologinya yaitu M8000/3. Penulisan kode neoplasma dengan tidak mencantumkan kode morfologi berpengaruh pada sifat neoplasma tersebut.

Pemberian kode diagnosis neoplasma di Rumah Sakit H.Adam Malik Medan tidak mencantumkan kode morfologi disebabkan oleh lembar hasil pemeriksaan patologi anatomi yang seringkali hasilnya datang terlambat. Hal ini sangat berpengaruh terhadap kode yang dihasilkan oleh petugas coding. 
Tabel 4. Analisis Ketepatan Kode Topografi Diagnosis Neoplasma

\begin{tabular}{clcc}
\hline No & Aspek Ketepatan Kode & Jumlah & Presentase \\
\hline 1. & Tepat 4 karakter & 79 & $85 \%$ \\
\hline 2. & Tepat 3 karakter & 8 & $9 \%$ \\
\hline 3. & Tepat 2 karakter & 4 & $4 \%$ \\
\hline 4. & Tepat 1 karakter & 0 & 0 \\
\hline 5. & Tidak tepat sama sekali & 2 & $2 \%$ \\
\hline 6. & Tidak dikode & 0 & 0 \\
\hline & Total & $\mathbf{9 3}$ & $\mathbf{1 0 0 \%}$
\end{tabular}

Sumber: Data Sekunder Rekam Medis Tahun 2019

Pada tabel 4 diatas dapat dilihat mengenai ketepatan kodetopografi diagnosis neoplasma tahun 2019 pada dokumen rekam medis rawat inap di Rumah Sakit H.Adam Malik Medan yaitu masih terdapat kode yang tidak tepat. Setelah di analisis ketepatannya berdasarkan tiap-tiap karakter, maka dapat diperoleh hasil 79 (85\%) kode tepat 4 karakter, $8(9 \%)$ kode tepat 3 karakter, $4(4 \%)$ kode tepat 2 karakter, $0(0 \%)$ kode tepat 1 karakter, 0 $(0 \%)$ kode tidak tepat sama sekali dan $0(0 \%)$ kode tidak dikerjakan. Dari hasil penelitian dengan menggunakan alat bantu pedoman wawancara untuk mengetahui bagaimana proses pengodean neoplasma di Rumah Sakit H.Adam Malik Medan di kode secara manual. Ternyata pengodean diagnosis neoplasma menggunakan buku ICD-10. Petugas coding ternyata mengode keadaan morfologinya menggunakan ICD-10.

Berdasarkan hasil analisa terhadap ketepatan kode topografi kasus neoplasma di Rumah Sakit H.Adam Malik Medan bulan Januari sampai dengan Maret 2019 (lihat tabel 3), dapat dilihat bahwa presentase ketepatan kode toprografi pada diagnosis neoplasma menunjukkan masih ada yang belum tepat. Presentase pada hasil analisis ketepatan kode topografi pada diagnosis neoplasma dengan kategori tepat 4 karakter menunjukkan angka yang tinggi yaitu $85 \%$. Sedangkan presentase ketepatan kode topografi pada diagnosis neoplasma dengan kategori tepat 3 karakter menunjukkan angka 9\% dengan kata lain dari 93 dokumen rekam medis rawat inap yang digunakan sebagai sampel terdapat 8 dokumen rekam medis rawat inap yang hasil kodenya tepat 3 karakter.

Pada tabel 4 dapat dilihat bahwa kategori ketepatan kode diagnosis tidak semuanya tepat 4 karakter. Jika spesifikasi kode pada ICD-10 mencantumkan kategori sampai 4 karakter, maka penentuan kode harus tepat sampai karakter terkahir. Bahwa sub kategori 4 karakter digunakan paling tepat untuk identifikasi (WHO, 2010).

Ketepatan kode topografi pada diagnosis kasus neoplasma di Rumah Sakit H.Adam Malik Medan bulan Januari sampai dengan Maret 2019 tergolong tinggi. Kode yang tepat sampai 3 karakter yaitu 9\% atau sekitar 8 kode diagnosis dari 93 kode diagnosis yang diteliti ketepatnnya. Kode tepat 3 karakter dapat digunakan dalam proses pelaporan misalnya RL2b. Ketepatan kode diagnosis sangat berpengaruh sebagai dasar pembuatan laporan yang penting, seperti laporan data keadaan morbiditas, dan laporan sepuluh besar penyakit.

Penggunaannya kode diagnosis yang tepat harus ditegakkan untuk mengidentifikasi diagnosis yang spesifik dan prosedur klinik pada klaim, pengisian form dan transaksi elektronik (AHIMA, 2009). Kualitas data terkode merupakan hal penting bagi kalangan tenaga personal Manajemen Informasi Kesehatan. Ketepatan data diagnosis sangat krusial di bidang manajemen data klinis, penagihan biaya, beserta hal-hal yang berkaitan dengan asuhan pelayanan kesehatan (Hatta, 2010). 


\subsection{Pembahasan}

\section{Faktor yang Menyebabkan Ketidaktepatan Kode Diagnosis Neoplasma di Rumah} Sakit H. Adam Malik Medan

Dari hasil penelitian mengenai ketepatan kode diagnosis neoplasma di Rumah Sakit H. Adam Malik Medan diperoleh faktor-faktor penyebab yang mengakibatkan ketidaktepatan kode diagnosis. Faktor-faktor tersebut antara lain yaitu:

a. Sumber Daya Manusia

Setiap petugas coding memiliki kesulitan yang hampir samadalam menentukan kode diagnosis yang tepat. Kesulitan tersebut berupa kesulitan membaca tulisan dignosis yang ditulis oleh dokter. Berikut merupakan hasil observasi peneliti mengenai tulisan diagnosis yang ditulis oleh dokter:

Tabel 5. Check List Observasi Tulisan Dokter

\begin{tabular}{lllc}
\hline No & \multicolumn{1}{c}{ Aspek yang diamati } & Ya & Tidak \\
\hline 1. & Tulisan menggunakan huruf kapital & \multicolumn{1}{c}{} \\
\hline 2. & Tulisan disingkat & $\sqrt{ }$ & \\
\hline 3. & Menggunakan istilah medis & $\sqrt{ }$ & \\
\hline
\end{tabular}

Ketepatan setiap hasil kode yang didapatkan bergantung dari kualitas petugas coding masing-masing. Petugas coding memiliki kemampuan dan pemahaman yang berbeda. Begitu juga ketelitian setiap petugas coding juga berbeda. Hal tersebut dapat menjadi faktor yang menyebabkan ketidakepatan kode diagnosis.

Berdasarkan hasil wawancara dengan petugas coding di Rumah Sakit H.Adam Malik Medan faktor yang menyebabkan ketidaktepatan kode diagnosis adalah petugas coding masih kesulitan dalam membaca tulisan dokter. Menurut Permenkes Nomor 55 Tahun 2013 Petugas coding juga menyatakan bahwa yang bertanggungjawab dengan kode diagnosis adalah petugas coding rekam medis dan seorang perekam medis harus mampu melaksanakan sistem klasifikasi.

b. Standar Operasional Prosedur (SOP)

Dari hasil penelitian di Rumah Sakit H.Adam Malik Medan sudah ada Standar Operasional Prosedur (SOP) yang mengatur tentang penentuan kode diagnosis. Berdasarkan hasil penelitian mengenai Standar Operasional Prosedur (SOP) di Rumah Sakit H.Adam Malik Medan, sudah terdapat Standar Operasional Prosedur (SOP) mengenai tata cara pengodean diagnosis tetapi tidak dijelaskan secara rinci mengenai tata cara pengodean untuk kasus tertentu seperti neoplasma dalam hal pencantuman kode.

Standar Operasional Prosedur (SOP) mempunyai pengaruh besar dalam keberhasilan penyelenggaraan pelayanan kesehatan. Standar Operasional Prosedur yang tidak sesuai akan mengakibatkan kerugian yang besar seperti kesalahan dalam pelayanan kesehatan. Dalam Kepmenkes No. 04 tahun 2003 tentang kebijakan dan strategi desentralisasi bidang kesehatan disebutkan salah satu tujuan strategis adalah upaya penataan manajemen kesehatan. Salah satu langkah kunci dalam tujuan atau upaya penataan manajemen adalah dengan dibuatkan Standar Operasional Prosedur (SOP).

\section{Hasil Ketepatan Kode Diagnosis Neoplasma}

Dari 93 sampel yang diteliti untuk melihat ketepatan kode diagnosis neoplasma didapatkan hasil sebagai berikut:

Tabel 6. Hasil Perhitungan Ketepatan Kode Diagnosis Neoplasma

\begin{tabular}{ccc}
\hline Keterangan & Tidak Tepat & Persentase \\
\hline Morfologi & 88 & $95 \%$ \\
\hline Topografi & 79 & $85 \%$ \\
\hline
\end{tabular}



$(85 \%)$

Kode morfologi yang tidak tepat $88(95 \%)$ dan kode topografi yang tidak tepat 79

\section{KESIMPULAN}

Berdasarkan hasil penelitian yang dilakukan di RSUP H.Adam Malik Medan di bagian pengkodingan, yaitu:

1. Pengodean diagnosis neoplasma masih belum sesuai dengan kaidah ICD-10 Volume 2. Dengan persentase ketidaktepatan kode topografi diagnosis neoplasma adalah 9 (85\%) dan kode morfologi diagnosis neoplasma 88 (95\%) dengan jumlah populasi diambil dari 93 dokumen rekam medis.

2. Faktor yang menjadi penyebab ketidaktepatan pengodean adalah petugas koding sulit untuk membaca tulisan dokter.

\section{REFERENCES}

Dewa Gede, (2012) Deteksi Dini Kanker. Dalam: Onkologi Klinik. Edisi 2. Surabaya: Airlangga Universit Press, 175-177.

Irma Yunita (2016). "Ketepatan Kode Diagnosis Pada Kasus Neoplasma di Rumah Sakit Panti Wilasa Citarum Tahun 2015".

Peraturan Menteri Kesehatan Republik Indonesia Nomor 76 tahun 2016 tentang Pedoman Indonesian Case Base Goup (INA CBG) dalam Pelaksanaan Jaminan Kesehatan Nasional.

WHO. (2010) ICD-10. 10th revision. Vol-1. Tabular List. International Statistical Classification of Diseases and Related Health Problem. WHO.

\section{BIOGRAPHIES OF AUTHORS}

Johanna Christy, Gelar Sarjana diperoleh dari Universitas Sumatera Utara, Jurusan
Ilmu Kesehatan Masyarakat pada tahun 2014. Magister Kesehatan Masyarakat
diperoleh dari Universitas Sumatera Utara pada Tahun 2017. Saat ini aktif sebagai
pengajar di Program Studi D-4 Manajemen Informasi Kesehatan Universitas Imelda
Medan.

